OPEN ACCESS

Edited by:

Abhijit Mukherjee,

Indian Institute of Technology

Kharagpur, India

Reviewed by:

Alok Chandra Samal,

University of Kalyani, India

Srimanti Dutta Gupta,

Indian Institute of Technology

Kharagpur, India

*Correspondence:

Mohammed Hossain and

Prosun Bhattacharya

KTH-International Groundwater

Arsenic Research Group, Department

of Sustainable Development,

Environmental Science and

Engineering, KTH Royal Institute of

Technology, Teknikringen 76,

SE-100 44 Stockholm, Sweden mohhos@kth.se: prosun@kth.se

Specialty section:

This article was submitted to

Groundwater Resources and

Management,

a section of the journal

Frontiers in Environmental Science

Received: 08 December 2014 Accepted: 29 March 2015

Published: 11 May 2015

Citation

Hossain M, Rahman SN,

Bhattacharya P, Jacks G, Saha $R$ and

Rahman M (2015) Sustainability of

arsenic mitigation interventions - an evaluation of different alternative safe

drinking water options provided in

Matlab, an arsenic hot spot in

Bangladesh. Front. Environ. Sci. 3:30.

doi: 10.3389/fenvs.2015.00030

\section{Sustainability of arsenic mitigation interventions - an evaluation of different alternative safe drinking water options provided in Matlab, an arsenic hot spot in Bangladesh}

\author{
Mohammed Hossain ${ }^{1,2 *}$, Shamsun N. Rahman ${ }^{2}$, Prosun Bhattacharya ${ }^{1 *}$, Gunnar Jacks ${ }^{1}$, \\ Ratnajit Saha ${ }^{2}$ and Marina Rahman ${ }^{2}$ \\ ${ }^{1}$ KTH-International Groundwater Arsenic Research Group, Department of Sustainable Development, Environmental Science \\ and Engineering, KTH Royal Institute of Technology, Stockholm, Sweden, ${ }^{2}$ NGO-Forum for Public Health, Dhaka, Bangladesh
}

The wide spread occurrence of geogenic arsenic in Bangladesh groundwater drastically reduced the safe water access across the country. Since its discovery in 1993, different mitigation options tested at household and community scale have resulted in limited success. The main challenge is to develop a simple, cost-effective, and socially acceptable option which the users can install, operate and maintain by themselves. In an arsenic hotspot of southeastern Bangladesh, 841 arsenic removal filter (ARF), 190 surface water filter membrane, 23 pond sand filter (PSF), 147 rain water harvester (RWH) and 59 As-safe tubewell were distributed among the severely exposed population by AsMat, a Sida supported project. After 3-4 years of providing these safe water options, this study was carried out during 2009-2010 for performance analysis of these options, in terms of technical viability and effectiveness and thus to evaluate the preference of different options to the end users. Household and community based surveys were done to make an assessment of the current water use pattern as impact of the distributed options, overall condition of the options provided and to identify the reasons why these options are in use and/or abandoned. In total, 284 households were surveyed and information was collected for 23 PSF, $147 \mathrm{RWH}$, and 59 tubewells. None of the filters was found in use. Among other options distributed, 13\% of PSF, $40 \% \mathrm{RWH}$, and $93 \%$ of tubewell were found functioning. In all cases, tubewells were found As-safe. About $89 \%$ of households are currently using tubewell water which was $58 \%$ before. Filter was abandoned for high cost and complicated maintenance. The use of RWH and PSF was not found user friendly and ensuring year round water quality is a big challenge. Arsenic-safe tubewell was found as a widely accepted option mainly because of its easy operation and availability of water, good water quality and negligible maintenance. This study validated tubewell as the most feasible drinking water supply option and this evaluation holds significance for planning water supply projects, improving mitigation policy as well as developing awareness among users.

Keywords: drinking water, arsenic, mitigation, alternative options, tubewells, users' preference 


\section{Introduction}

Access to safe supply of water is fundamental to a country's development and a basic human right worldwide. Bangladesh is one of the most disaster prone and also densely populated countries. It has a population of more than 139 million in an area of 147,570 $\mathrm{km}^{2}$ and about $81 \%$ live in the rural areas (BBS, 2011). Before the 1970s surface water was the only water supply source for the rural population and was the main reason for a high level of infant mortality due to the prevalence of gastrointestinal diseases and cholera. From the 70s however people were made aware of the bacteriological threat of using surface water. This led people to change their habit and to switch to using pathogen free groundwater. In this context Bangladesh had achieved a remarkable success in the supply of safe water by using groundwater based technologies such as tubewells. At the end of 1990s nearly $100 \%$ of the urban and $97 \%$ of the rural population of Bangladesh had access to pathogen free water. However, in the late 1990s it became apparent that the tubewells installed mostly in shallow aquifers contain high levels of arsenic.

According to the BGS and DPHE (2001), 57 million people in Bangladesh in 1999 were exposed to arsenic through drinking water containing As concentrations exceeding the WHO guideline value of $10 \mu \mathrm{g} / \mathrm{L}$ and 35 million by the Bangladesh Drinking Water Standard (BDWS) of $50 \mu \mathrm{g} / \mathrm{L}$. The second national survey conducted in 2009 by BBS/UNICEF (2011) indicated the exposures as 53 and 22 million respectively with respect to WHO guideline and BDWS. At present arsenic has been detected in groundwater in 322 upazilas and in 61 out of 64 districts of Bangladesh.

Since discovery of arsenic in Bangladesh groundwater in 1993, although a significant progress has been achieved to understand the science related to the origin, occurrence and distribution pattern of arsenic in groundwater, success in mitigation attempts is limited (Mukherjee and Bhattacharya, 2001; Bhattacharya et al., 2002; van Geen et al., 2003, 2008; Ahmed et al., 2004, 2006; Shamsudduha and Uddin, 2007; von Brömssen et al., 2007). In the context of plan and expectations, true mitigation has progressed much more slow (Johnston et al., 2014) and hence the public health burden remains very high. Flanagan et al. (2012) estimated that only As contamination could cause annual death of 24,000 and 19,000 adults in Bangladesh at concentration levels of $>50 \mu \mathrm{g} / \mathrm{L}$ and $10-50 \mu \mathrm{g} / \mathrm{L}$ respectively. In a situation of very limited mitigation success, the main challenge is to develop and promote a sustainable option that the community can adopt, install and maintain by themselves and obviously that signifies the relative acceptance of the options to the affected community, although, some specific geomorphic and geological set-up could limit the choice to a certain type in some areas, such as, higher salinity in the southwestern region of the country, sub-surface boulders in hilly areas of northeast.

Efficiency and success of arsenic mitigation, in general, greatly lies with the findings from both technical and social sciences (Johnston et al., 2014) and hence it is important to evaluate the performance of the alternative safe water options provided and to understand the context of technical suitability and social relevance of the success and/or failure of the options.
Although the efforts are given to make safe water available to the end users, the roles of other stakeholders involved in the process of mitigation have significant impact on the end result. In a recent study, Johnston et al. (2014) explained how technical, psychological and institutional factors could influence the mitigation efforts. Arsenic in Bangladesh groundwater is geogenic and the mitigation approach could vary considerably with the variation in natural settings of sub-surface geologic materials along with the variation of hydro-meteorological conditions and socioeconomic status of different areas. Similarity in the relevant conditions favored the nature and extent of arsenic exposure which is similar to a large part (old and recent flood plain) of the country. This makes the situation favorable to develop mitigation approach and thereafter bring meaningful changes, if the mitigation measure is selected properly and recognized by the whole range of stakeholders, such as, policy people, decision makers, facilitating and implementing agencies, development partners, social workers, and end users.

This manuscript presents a study on the evaluation of different alternative safe drinking water options carried out during 20092010, after 3-4 years of implementation of the options in Matlab, an arsenic hot spot under Chandpur district in southeastern Bangladesh. A small area of the neighboring Daudkandi upazila is also included in the study area. These safe water options were provided under the Sida financed project "Arsenic in tubewell water and health consequences in Matlab Upazila of Chandpur district-AsMat" (AsMat Final Report, 2007). This manuscript includes the findings on acceptance of the water options by the users, change of water use pattern as an impact of the provided safe water options, and the performance of the options after a certain period of implementation (SASMIT Unpublished Report $2010)^{1}$, which creates messages in the context of sustainability of the options from technical and social perspectives. This kind of information based on the evaluation of the safe water options could be useful for planning and implementation of true measures which would allow us to give our efforts for bringing a visible change in arsenic mitigation to make it sustainable. This would also be helpful to optimize the use of resources and time.

In terms of objective, this study has (a) determined the source for collecting water for domestic use, to identify the water supply option preferred by the community; (b) assessed the overall condition of the distributed options in order to identify the reasons behind the success and/or failure of the options, (c) checked the water quality of both surface water and groundwater based options which were found functional to make a cross-check with the information collected from the end users.

\section{Materials and Methods}

\section{The Study Area}

Matlab region is an arsenic hot-spot (Figure 1A) located in the southeastern part of Bangladesh at a distance of about $60 \mathrm{~km}$

\footnotetext{
${ }^{1}$ SASMIT Annual Report. (2010). Sustainable Arsenic Mitigation (SASMIT) Community driven initiatives to target arsenic safe groundwater as sustainable mitigation strategy (Sida Contribution No.:73000854). 2nd Year Annual Report (April 2009-March 2010), KTH-International Groundwater Arsenic Research Group, Department of Sustainable Development, Environmental Science and Engineering, KTH Royal Institute of Technology, Stockholm, Sweden, 38p.
} 

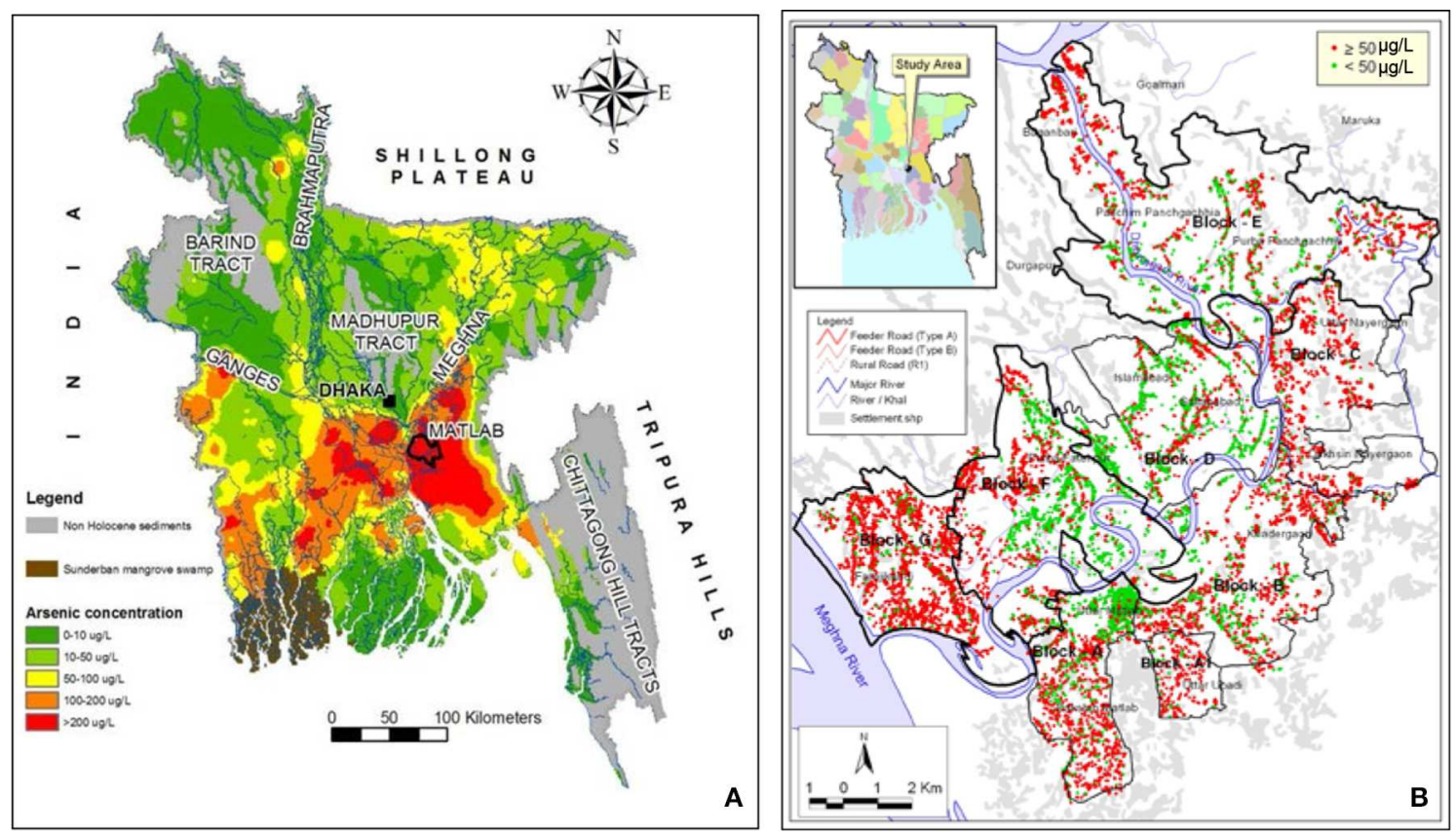

FIGURE 1 | (A) Matlab region in Bangladesh map and (B) the study area showing green dots for the tubewells with As concentrations $<50 \mu \mathrm{g} / \mathrm{L}$ and red dots for those with $\geq 50 \mu \mathrm{g} / \mathrm{L}$ (modified from Jakariya et al., 2007).

from Dhaka city. This study was carried out only in a certain portion of Matlab (about 50\%) where International Center for Diarrhoeal Disease Research, Bangladesh (ICDDR, B) has been running a health and demographic surveillance system since 1996. The ICDDR,B intervention area is extended to 142 villages covering an area of 18,386 hectares of land with a population of about 220,000 as of 2003 (AsMat project Final Report, 2007). Under AsMat project, jointly implemented by ICDDR,B and BRAC, a detailed screening of all drinking water tubewells $(n=12.532)$ in the intervention area was carried out through Astesting by field kits and laboratory analysis (AsMat Final Report, 2007; Jakariya et al., 2007). The severity of As-contamination in the study area was indicated by exceedance of WHO guideline value of $10 \mu \mathrm{g} / \mathrm{L}$ in $72 \%$ wells and Bangladesh drinking water standard (BDWS) of $50 \mu \mathrm{g} / \mathrm{L}$ in $64 \%$ wells (Figure 1B). The severity of arsenic exposure was also evident from a social survey conducted by a parallel study (SASMIT Unpublished Report $2012)^{2}$ in 96 villages of the Matlab region, most of which are located outside this study area that found only $18 \%$ (average) of total operating tubewells produce As-safe water.

To reduce the risk of arsenic toxicity, different alternative safe drinking water options (Table 1) were provided by AsMat project (terminated in 2006) based on certain criteria. Villages where $50 \%$ or more tubewells were found to be contaminated were

${ }^{2}$ SASMIT Annual Report. (2012). Sustainable Arsenic Mitigation (SASMIT)Community driven initiatives to target arsenic safe groundwater as sustainable mitigation strategy (Sida Contribution No.:73000854). 4th Year Annual Report (April 2011-March 2012), KTH-International Groundwater Arsenic Research Group, Department of Sustainable Development, Environmental Science and Engineering, KTH Royal Institute of Technology, Stockholm, Sweden 2012; 82p.
TABLE 1 | Safe drinking water options provided among the users.

\begin{tabular}{|c|c|c|}
\hline Type of option (s) & Option's name & $\begin{array}{l}\text { No. of options } \\
\text { distributed }\end{array}$ \\
\hline \multirow{3}{*}{$\begin{array}{l}\text { Household based arsenic } \\
\text { contaminated groundwater } \\
\text { treatment option: Arsenic } \\
\text { Removal Filter (ARF) }\end{array}$} & Safi filter & 24 \\
\hline & 3-Pitcher filter & 99 \\
\hline & Alcan filter & 718 \\
\hline $\begin{array}{l}\text { Household based arsenic free } \\
\text { surface water treatment option }\end{array}$ & Bishudhya filter & 190 \\
\hline $\begin{array}{l}\text { Community based slow sand } \\
\text { filtration system }\end{array}$ & Pond sand filter (PSF) & 23 \\
\hline $\begin{array}{l}\text { Household based rain water } \\
\text { system }\end{array}$ & Rain water harvester $(\mathrm{RWH})$ & 147 \\
\hline $\begin{array}{l}\text { Community based groundwater } \\
\text { option }\end{array}$ & Tubewell (As-safe) & 59 \\
\hline
\end{tabular}

considered and within the targeted villages, poor households were given the priority for the distribution of house-hold based options. For community based options, sites were selected in those localities where most tubewells were found contaminated. In addition to improve the condition of safe water access, the other reason for distributing these options was to make an assessment of the sustainability of the options based on certain criteria, such as, cost (initial and maintenance) for supply of water, As removal capacity, susceptibility to bacteriological contamination and acceptability to the community (Jakariya et al., 2005).

\section{Brief Description of the Water Options Provided}

A brief description of various safe drinking water options provided among the people exposed to drinking water with severe arsenic contamination is given below. 


\section{Arsenic Removal Filter (ARF)}

Arsenic is filtered out from contaminated groundwater using different kinds of filter materials/membranes. Among them commonly used filters (Figure 2A), such as, Safi filter, three-pitcher filter and Alcan filter were provided in the study area.

(a) Safi filter, named after the inventor Professor Sayeed Safiullah, who designed and developed this device locally in Bangladesh to remove both arsenic and pathogenic bacteria. This filter is consisting of two concrete buckets of same capacity (15-20 L), one with filter is placed on the top of the other. Arsenic contaminated water from the upper bucket flows down to the lower bucket through a ceramic permeable candle. Purified water is then taken out through a tap hooked with the lower bucket. One small filter is designed to filter about 40 liters of water per day.

The candle is made of a chemical mixture of aluminum hydroxide, ferric oxide, manganese dioxide, porous silica and laterite soil. This mixture adsorbs arsenic as the water passes through the candle. It is also claimed that the candle eliminates pathogenic bacteria from the contaminated water. According to the version of manufacturer, the candle is to be replaced with a fresh one in every 2 years.

(b) Three-pitcher filter, the very name reflects that it comprises three pitchers, made of clay, locally called as "Kolshi" in Bangla, and therefore it is also called "three-kolshi filter." This is a modified version of the indigenous method of filtration that has long been used in Bangladesh to remove suspended particles from surface water and during the last few decades to remove iron from tubewell water. Traditionally two-pitcher method is used to filter water but for removal of arsenic, it has been modified to a three-pitcher system. The top pitcher contains coarse sand covered with iron fillings as the source of iron oxide which adsorbs arsenic effectively from contaminated water (Khan et al., 2000). The second pitcher contains sand and charcoal and finally the third pitcher receives the filtered water. This method remains quite effective in first 4-6 weeks and then efficiency for arsenic removal starts to decline. Rate of filtration is slow and could produce 1-2 liters in an hour. This unit needs to be replaced usually in every 3-4 months as the efficiency declines and filter becomes clogged from iron filings. Bacteriological contamination in effluent water could be a concern in this method.

(c) Alcan Filter, is a removal process, in which arseniccontaminated water is passed through a sorption medium which removes arsenic. Alcan filter is one such and made of iron-enhanced activated (AAFS50), a globally patented highly effective adsorptive material. This is an imported foreign technology and well-designed and seems efficient in arsenic removal. It needs periodical change of the activated alumina which needs to be imported. Cost for installation and maintenance is a concern-initial cost is high for both community based option and the household based unit (Jakariya et al., 2007). Replacement of filter media also requires a reasonable cost and usually needed after filtration
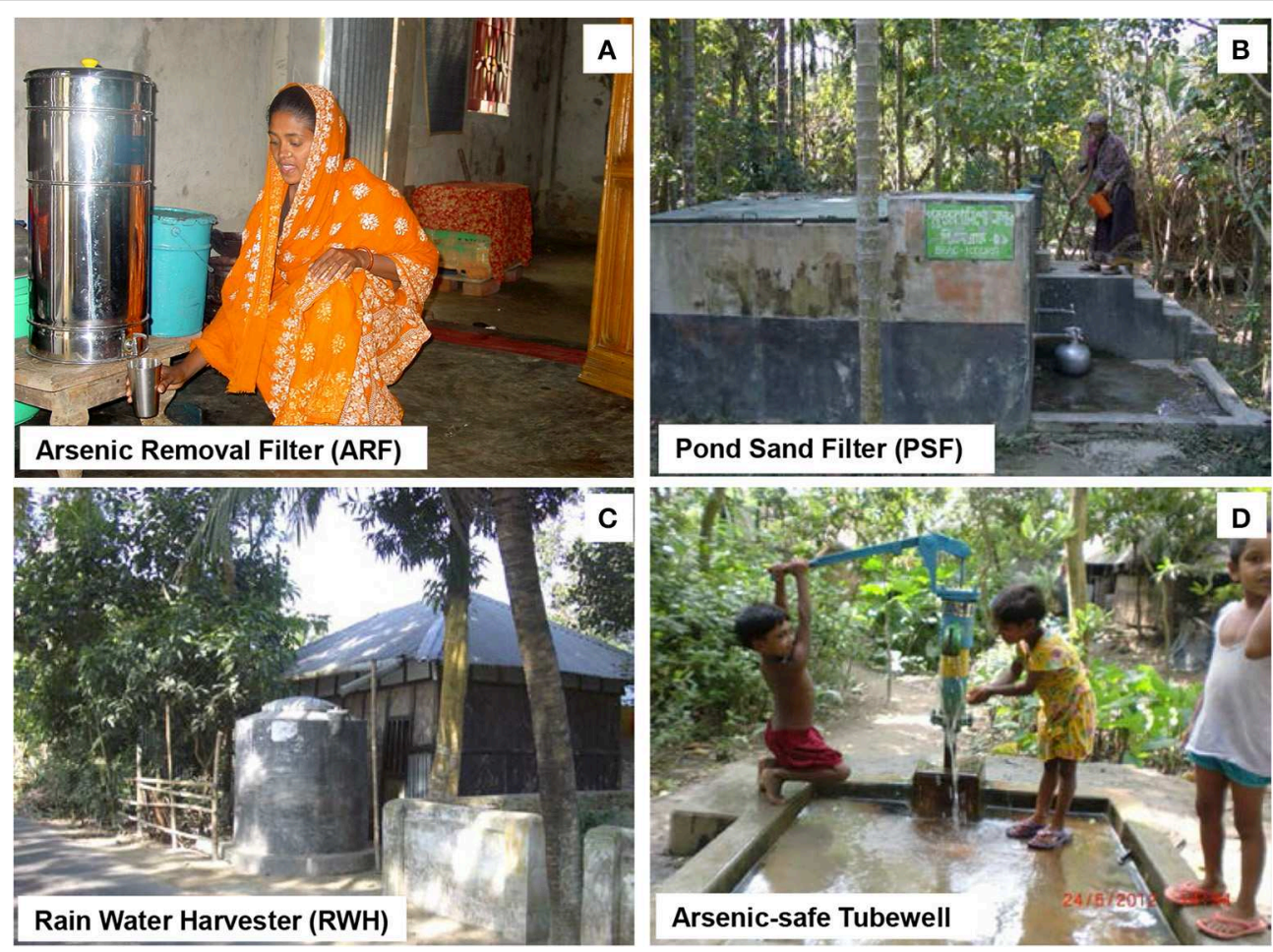

FIGURE 2 | Different options of As-safe drinking water (A) Arsenic Removal Filter (B) Pond sand Filter (C) Rain Water Harvester (D) As-safe Tubewell. 
of 80,000 and 11,000 liters of water by community and household units respectively (Jakariya et al., 2007). Apart from the cost which seems to discourage villagers, disposal of used material is also another issue of concern not only for Alcan filter but also for all other arsenic removal filters available in Bangladesh. These two issues need to be monitored properly to avoid further hazard.

\section{Bishudhya Filter}

Unlike the ARFs, this filter is used to remove bacteria from surface water, which is arsenic free. This is locally produced and relatively inexpensive and in terms of filtration and purification method this option is similar to pond sand filter (PSF). Locally available rocks are used to produce mesh of different sizes to be used as filters. For removing bacteria, the water is passed through different layers before it reaches the storage chamber. Depending upon the type of suspended load in raw surface water, it needs washing of the materials after a certain interval. Foodgrade plastic is used for making the plastic container. This option could be ideal where year round surface water is available and the water is free from industrial effluents (chemicals) and agricultural washouts (fertilizers and pesticides).

\section{Pond Sand Filter (PSF)}

Pond water is pumped into a concrete reservoir (Figure 2B) which is constructed with a provision of filtering water through sand and gravel. According to DPHE/JICA (2009), the number of population served by a PSF on an average is 90 . In an earlier survey conducted in three arsenic affected upazilas namely Bhanga, Muradnagar, and Sirajdikhan by Johnston and Sarker (2007) this number was reported as 180 . Gravel and fine sand are used as the filtering material in PSF. Cleaning of the gravel chambers at a certain interval is required to ensure the water quality. For the last few decades, ponds protected only for drinking and cooking water have been used in the coastal areas of Bangladesh where shallow groundwater is saline and identifying freshwater aquifer is a difficult task and expensive. In the recent years, PSFs are also used as an alternative water option in the context of arsenic contamination, but yet now, significant use of this option is visible mostly in the salinity prone area, more specifically in the southwest region of the country. No chemical treatment is involved in this process and therefore this can be considered as an option with no/little effect on the environment. But the greatest challenge for this option is to find suitable ponds which are protected from pisciculture and other household activities including bathing and washing clothes. Availability of year round water is also an important concern.

\section{Rain Water Harvesters (RWH)}

Rainwater harvesting can be simply defined as the collection of surface water run-off generated from rain for the purpose of human use. In the most common technology, rooftop is used as the catchment from where the rain is collected and stored in a container placed at the corner/edge of the house (Figure 2C). In a country like Bangladesh with high rainfall, RWH could be a useful water supply option. First flush by using an initial flushing device (Islam et al., 2014) could be helpful to get rid of the dirt and other impurities which are collected to the tank from the rainwater flow over the catchment. Maintenance requires periodical cleaning of the tank especially before the monsoon (major rainfall) period starts. Mainly it includes removal of leaves, dirt and other materials accumulated in the tank. It also needs checking the gutters and down-pipes. It has been traditionally used for many years in the southwest region of the country where surface water salinity is impacted from the tidal effects and locating freshwater aquifer within a reasonable depth is nightmare in most places. Khan et al. (2014) identified RWH as a suitable and popular option in the coastal regions of the country where water supply from deep tubewells or piped supply system is limited because of groundwater salinity. For rural water supply, RWH has been used in Asia and Africa and its history in Asia can be traced back even to the 9th or 10th Century (UNEP Newsletter and Technical Publication $)^{3}$. Availability of water and degraded water quality during the dry months are important concerns. Average population served by a RWH quoted in DPHE/JICA (2009) is 5 in number, that is, average population of one $\mathrm{HH}$.

\section{Tubewell}

This technology consists of a tube or pipe bored into a subsurface sandy layer which can store and transmit water. A strainer (filter) is fitted at the lower end of the tube and a pump at the top to lift water (Figure 2D). Most commonly used hand tubewell (HTW) in Bangladesh is known as No. 6 pump-a lever operated suction pump. This can lift water as long as the water level is within a depth of 6.5 meter. The depth of the well depends upon the depth of the targeted aquifer. In the current practice, steel pipe is used for the uppermost $4-5 \mathrm{ft}$ section on the top of which the hand pump is installed and the remaining portion consists of PVC pipes. Standard diameter of the tube is $1.5 \mathrm{inch}$. Since the use of HTW began in 1970s, the dependence on this technology is constantly increasing and at present Bangladesh people are using about 10 million tubewells, $90 \%$ of which are installed privately by the local drillers as the local initiative of the end users.

\section{Study Design and Methods Used}

Household survey and water options survey were the main tools of this study along with some water quality testing. The whole study was done in the following two stages.

\section{Household $(\mathrm{HH})$ Survey}

In the first stage, household survey was conducted to assess the current water use pattern which reflects the safe water options preferred by the users to whom the alternative options were provided. This survey also allowed us to know the current status of all kinds of filters which were provided as household based option.

From the perspective of living set-up in rural Bangladesh, household is considered as the basic survey unit. Usually, a number of households comprise a "bari" (cluster of households) and in our standard practice in a rural area we locate/identify a targeted person, family or household with respect to the bari. A household can be defined (Khan et al., 2009) as a family where all the members live communally and share income, food, water

${ }^{3}$ UNEP Newsletter and Technical Publications (http://www.unep.or.jp/ietc/ publications/techpublications/techpub-8e/rainwater2.asp). 
TABLE 2 | Household (HH) survey plan and coverage.

\begin{tabular}{|c|c|c|c|c|}
\hline Type of safe water option & No. of installations surveyed & No. of HH targeted per option & No. of HH surveyed for each type & Total HH surveyed \\
\hline RWH (Household based option) & 44 & $1 \mathrm{HH}$ surveyed for each RWH & 44 & 284 \\
\hline PSF (Community based option) & 20 & $5 \mathrm{HH}$ surveyed for each PSF & 100 & \\
\hline Tubewell (Community based option) & 28 & $5 \mathrm{HH}$ surveyed for each Tubewell & 140 & \\
\hline
\end{tabular}

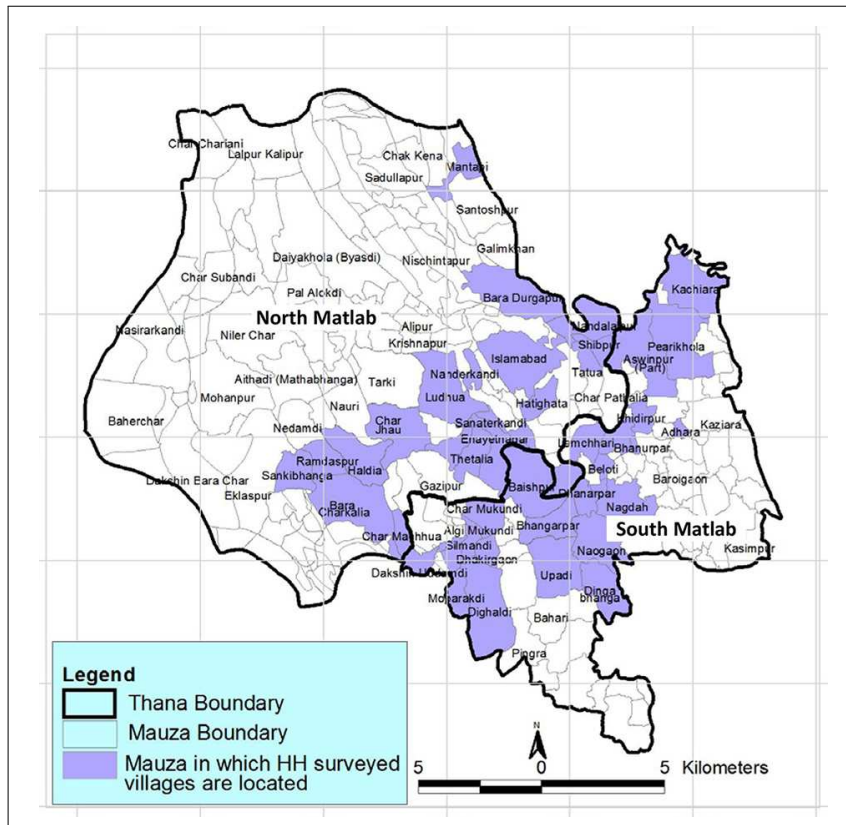

FIGURE 3 | Mauzas in which HH surveyed villages are located.

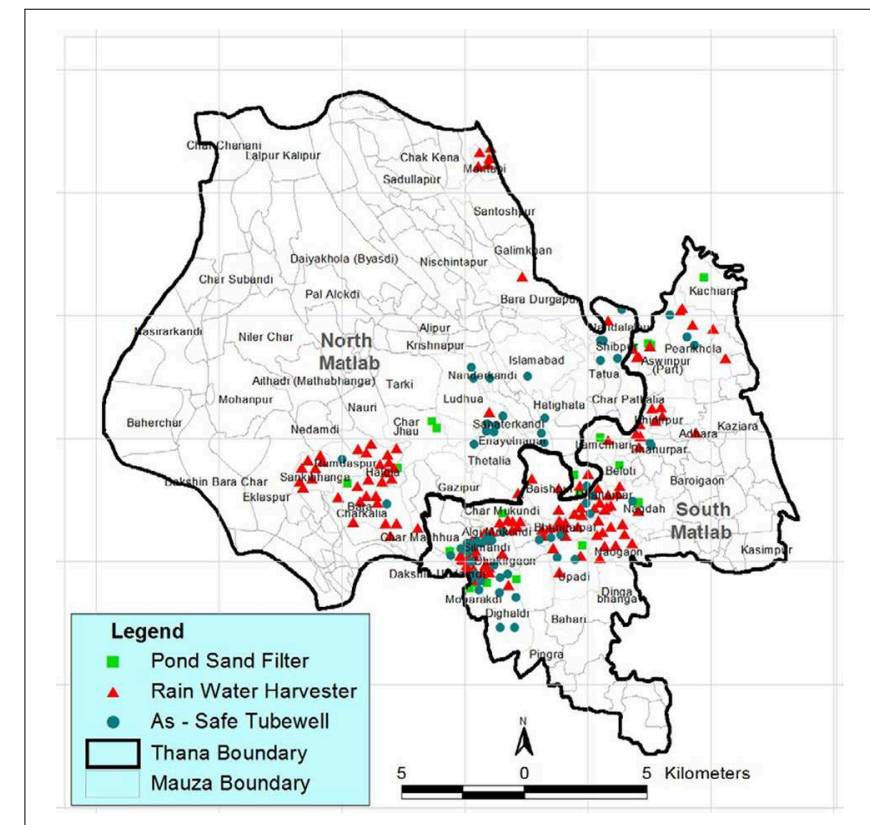

FIGURE 4 | Locations of the safe water options surveyed.

TABLE 3 | Type and number of safe water options surveyed.

\begin{tabular}{lcc}
\hline Type of safe water option (s) & $\begin{array}{c}\text { Installations surveyed } \\
\text { under each category }\end{array}$ & $\begin{array}{c}\text { Total no. of } \\
\text { installations } \\
\text { surveyed }\end{array}$ \\
\hline RWH (Household based option) & 147 & 229 \\
PSF (Community based option) & 23 & \\
Tubewell (Community based option) & 59 &
\end{tabular}

related to livelihood and standard of living, such as, monthly income, monthly expenditure for food and other purposes, availability of food, type of house in which the families live and whether they had any savings in the last 1 year. Among 284 households surveyed, 269 are spread over 49 villages in 13 unions of Matlab south and Matlab north upazilas (Figure 3). Another $15 \mathrm{HH}$ were surveyed from 4 villages of neighboring Daudkandi upazila, being a part of AsMat intervention area.

\section{Water Options Survey}

In the second stage, information was collected for all PSF, RWH and tubewells to assess the present status of the options (technologies) in the field. By means of physical visit at the respective sites and through collection of information for all PSF, RWH 
and tubewells, this stage of study was designed to assess the current status of the options (technologies). Figure 4 shows the locations of the options surveyed and Table 3 provides the number of options surveyed under each category. Survey was done using short semi-structured questionnaire. Surveyor's findings were also included.

In addition to make assessment of the technological options based on their physical structure and functionality, surface water based technology (RWH and PSF) were tested for bacterial threat and arsenic testing was done by Digital Arsenator for the groundwater based technology (tubewell). Measurement of arsenic in tubewell water was also used to evaluate the groundwater arsenic concentration in these tubewells over time in the context of sustainability. These tests also allowed us to make a kind of cross-check with the statements made by the users.

A simple questionnaire was used in options survey. Data was collected on the number of users in terms of family, purpose of water use, how long they have been using the surveyed option and availability of water round the year. When the option was found non-functional, information was collected on how long the option had been non-functional along with the causes. In addition to record the coordinates (latitude and longitude) of the options using GPS, surveyor's own findings based on his observation were also documented for the analysis. SPSS version 11.5 was used for data entry and analysis of the survey result.

\section{Results}

\section{Socio-Economic Characteristics of the Water Option Users}

Majority of the respondents (55\%) are male and around 45 years old. Average age of the respondents was 42 with a little higher for male and lower for female. Male-female proportion along with age based statistics is provided in Table 4.

TABLE 4 | Age wise gender based demographic statistics of the respondents.

\begin{tabular}{lcccccccc}
\hline Category & \multicolumn{2}{c}{ Population } & & \multicolumn{5}{c}{ Age (year) } \\
\cline { 2 - 5 } & Total (n) & $\%$ & & Min & Max & Mean & Median & StdD \\
\hline All & 284 & 100 & 18 & 85 & 42 & 41 & 14 \\
Female & 128 & 45 & 18 & 80 & 38 & 35 & 13 \\
Male & 156 & 55 & 18 & 85 & 45 & 45 & 15
\end{tabular}

About $81 \%(n=126)$ male respondents are head of the HHs and remaining $19 \%$ are their descendants. On the contrary, $75 \%$ of the female respondents $(n=128)$ are spouses, $13 \%$ head of households, and remaining $12 \%$ comprise from other relations like daughter, daughter-in-law, sister, mother, etc. only.

Calculation made through distribution of the interviewed population into different classes provided a clear overview of the educational status of the samples. The proportion of the respondents under all these eight classes with respect to the total, male and female numbers are given in Table 5. Excepting the class "only can sign," males are relatively ahead of the females. Higher rate of literacy was observed among the relatively younger respondents.

Three different categories that reflect no institutional education, such as, illiterate, only can sign and informal education constitute the major proportion of the respondents, although the level of education is extremely varying (Figure 5).

Monthly average income, availability of food all time for all household members and cash savings from last 1 year provide an overall economic condition of the households surveyed. The variation in income range is quite high, although about half of the population has an average income of 4000-6000 Bangladesh Taka (BDT) per month per family. Proportion of households with corresponding monthly income is listed in the Table 6.

About $45 \%$ of the populations surveyed always have sufficient food for their family, and almost same numbers of populations have deficit for sometimes only. A few (6.7\%) are in all-time deficit and a very few have surplus always. About half of the populations had no cash savings in the last 1 year and the remaining half had savings of varied range mostly within an amount of 10 thousand taka.

\section{Current Status of Different Safe Water Options Provided and the Reasons of Non-Functionality}

The current status along with the performance assessment of different safe water options are presented in this section. This also includes the reasons which favored the users to prefer a particular option to use as a safe water source and the causes why an option has been abandoned and found not in use. Table 7 illustrates the summary of the current status of different options.

Figure 6 shows the relative abandonment of different options provided, which was $100 \%$ in all types of filters. For PSF and RWH, it was 87 and $60 \%$ respectively. The best condition was found with the arsenic-safe tubewells - only $7 \%$ was found not in operation and the remaining $93 \%$ was in use.

TABLE 5 | Educational status of the respondents.

\begin{tabular}{|c|c|c|c|c|c|c|c|c|}
\hline Category & Illiterate & Only can sign & Informal education & Grade 1-5 & Grade 6-10 & SSC or equivalent & HSC or equivalent & Graduate \\
\hline Female & $13.3 \%$ & $51.6 \%$ & $7.8 \%$ & $10.9 \%$ & $11.7 \%$ & $1.6 \%$ & $2.3 \%$ & $0.8 \%$ \\
\hline$(n=128)$ & $(n=17)$ & $(n=66)$ & $(n=10)$ & $(n=24)$ & $(n=15)$ & $(n=2)$ & $(n=3)$ & $(n=1)$ \\
\hline Male & $3.8 \%$ & $31.4 \%$ & $12.2 \%$ & $14.1 \%$ & $19.9 \%$ & $9.6 \%$ & $7.1 \%$ & $1.9 \%$ \\
\hline$(n=156)$ & $(n=6)$ & $(n=49)$ & $(n=19)$ & $(n=22)$ & $(n=31)$ & $(n=15)$ & $(n=11)$ & $(n=3)$ \\
\hline All & $8.1 \%$ & $40.5 \%$ & $10.2 \%$ & $12.7 \%$ & $16.2 \%$ & $6 \%$ & $4.9 \%$ & $1.4 \%$ \\
\hline$(n=284)$ & $(n=23)$ & $(n=115)$ & $(n=29)$ & $(n=36)$ & $(n=46)$ & $(n=17)$ & $(n=14)$ & $(n=4)$ \\
\hline
\end{tabular}




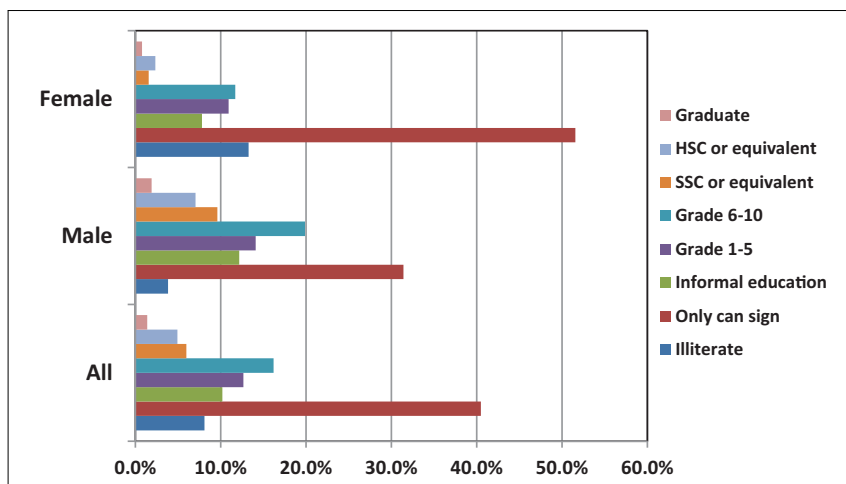

FIGURE 5 | Proportion of the respondents with respect to educational status.

TABLE 6 | Average monthly income of the HHs.

\begin{tabular}{lcc}
\hline Monthly income (Taka) & Number of HH & \% wrt total HH \\
\hline$<4000$ & 22 & $7.7 \%$ \\
$4000-6000$ & 141 & $49.6 \%$ \\
$6000-8000$ & 67 & $23.6 \%$ \\
$8000-10000$ & 29 & $10.2 \%$ \\
$10000-20000$ & 19 & $6.7 \%$ \\
$>20000$ & 6 & $2.1 \%$ \\
\hline
\end{tabular}

\section{Arsenic Removal Filters (ARF) and Bisudhya Filter}

None of the filters distributed was found to be operating in the study area. Filter was abandoned by the users mainly because of their high cost and complicated maintenance. In addition, the users have no idea about the sludge management also.

\section{Pond Sand Filter (PSF)}

Only three (3) PSF were found to be functional among 23 distributed in the study area. Within the period of the first 12 months, about $50 \%$ of the distributed PSF went out of operation and after 18 months about $75 \%$ became nonfunctional.

The major causes pointed out by the respondents as reason for failure or non-functionality of PSF are mostly related to technical feasibility and maintenance (Figure 7). Poor maintenance in turn affects the water quality and make this water unsuitable for use. The causes that came out in terms of the relative importance are-damage of the pipe connecting pond and PSF and no initiative of subsequent repair (33\%); breaking and stealing tubewell parts and PSF tape (22\%); users non-cooperation means maintenance difficulties (16\%); dirty and bad-smelled water (14\%); taking bath and washing in pond (7\%); fish culture $(4 \%)$; access to pipe water supply (2\%); and water level decrease in pond (2\%).

\section{Rain Water Harvester (RWH)}

Physical structure of 145 installations out of $147 \mathrm{RWH}$ were found to exist in field and among them 59 (40\%) were found working. These options are used at most for 6 months in the year. For the rest of the year the users depend on other sources which are not always safe in terms of arsenic and pathogenic contamination. Since RWH is a household based water supply option, operation and maintenance $(\mathrm{O} \& \mathrm{M})$ solely depends on the respective household. Most of the RWH were found to become inactive due to the costly maintenance system. Specific causes for the non-functionality of this system and the proportion of the interviewed respondents are-damage of the pipe collecting rain water from roof (43\%); damage of chakti, net, filter, tape, tank cover, etc. (21\%); maintenance problems (8\%); unavailability of water as a continuous source year round (7\%); dissatisfaction with the water quality (5\%); rotten leaves (4\%) which is also a water quality issue; broken base resultant from inappropriate site selection (4\%); changing, shifting and repairing the house (4\%); access to other year-round safe water options (3\%).

\section{Tubewell (TW)}

Although the physical structures of all 59 tubewells provided exist in the field, 55 tubewells were found to be properly functional and producing water at present. Tubewells found not in use were caused from no-maintenance, that is, the required accessories were not replaced by the respective caretakers. These wells were installed targeting red/off-white sands (Hossain et al., 2014) within the depth range of $55-85 \mathrm{~m}$ and in all cases the wells were opened to the people as they were found safe for drinking. Although 61 tubewells had been reported in AsMat report, but during field survey it was found that 59 tubewells were installedone well failed during installation and the other one was not made by the assigned driller.

\section{Users Preference for Options and their Performance}

A large number of people have switched to tubewells from the other water sources especially for drinking purpose. Summing the number of users collect water for the purpose of drinking only and for both drinking and cooking, $89 \%$ of the surveyed households use tubewell water. Whereas 3 years back, means before providing the safe tubewells, this statistic was $58 \%$ (Table 8). It means, as the impact of installation of safe tubewell, among all $284 \mathrm{HH}$ surveyed, $254 \mathrm{HH}$ use tubewell at present for collecting their drinking water, which was 165 before (Figure 8).

Among respondents, $29 \%$ are absolute tubewell users and they use tubewell water for both drinking and cooking. For drinking only, use of tubewell water has been raised from $32 \%$ to $60 \%$. It was also revealed from the survey that in these 3 years tubewell users have increased about $54 \%$ among the respondents. About $6 \%$ of the respondents switched back to river, pond or canal water for their cooking purpose. The results are summarized in Table 8.

During the same time period of 3 years of implementation, $73 \%$ PSF users and 76\% RWH users have switched to tubewells. The majority of users who switched water options, other than those initially using tubewells stated technological problem as the main reason for changing. It has been clearly revealed from this study that when a new technology is introduced in a locality, the users compare its feasibility first in terms of operation and maintenance with the existing technology. And once a user becomes familiar with the operation and maintenance of the new option then they consider and compare the quality of water of the new 
TABLE 7 | Current status of the safe water options distributed.

\begin{tabular}{|c|c|c|c|c|}
\hline Alternative safe drinking water option & Number of options distributed & Number of options in use & $\%$ of options in use & Remarks \\
\hline Safi filter & 24 & 0 & $0 \%$ & $\begin{array}{l}\text { Not accepted by the users } \\
\text { at all; none is functional }\end{array}$ \\
\hline 3 Pitcher filter & 99 & 0 & $0 \%$ & $\begin{array}{l}\text { Acceptance of the option by } \\
\text { users is not appreciable and } \\
\text { presently nonfunctional }\end{array}$ \\
\hline ALCAN filter & 718 & 0 & $0 \%$ & $\begin{array}{l}\text { Response was slow after } \\
\text { distribution, acceptance of } \\
\text { the option by users is not } \\
\text { appreciable }\end{array}$ \\
\hline Bishudhya filter & 190 & 0 & $0 \%$ & $\begin{array}{l}\text { Acceptance of the option by } \\
\text { users is not appreciable and } \\
\text { none is in use now }\end{array}$ \\
\hline PSF & 23 & 3 & $13 \%$ & $\begin{array}{l}\text { Technical feasibility and } \\
\text { maintenance are the main } \\
\text { concerns }\end{array}$ \\
\hline $\mathrm{RWH}$ & 147 & 59 & $40 \%$ & $\begin{array}{l}\text { Performance is appreciable } \\
\text { and people's acceptance is } \\
\text { good; water availability } \\
\text { limited to } 5-6 \text { months in a } \\
\text { year is an important concern }\end{array}$ \\
\hline Tubewell & 59 & 55 & $93 \%$ & $\begin{array}{l}\text { Acceptance to the society is } \\
\text { very high. Very much } \\
\text { appreciable to the users }\end{array}$ \\
\hline
\end{tabular}

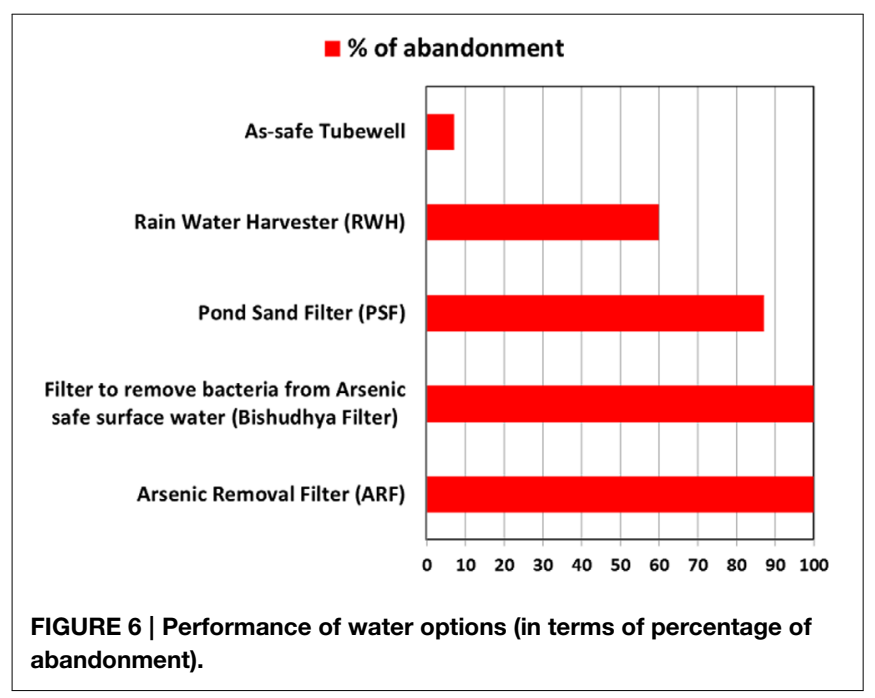

intervention with previous one. This indicates that in introducing options, users existing knowledge of operation and maintenance is an important concern.

The reasons stated by the respondents for switching water options from PSF and RWH to tubewell are given in Figures 9A,B.

For those who were using tubewell, the user's dissatisfaction was primarily due to the water quality, that is, arsenic contamination.

\section{Safe, Tested, Untested and Unsafe Tubewell User}

Since the safe water options provided among the surveyed households, more new tubewells have been installed by this time

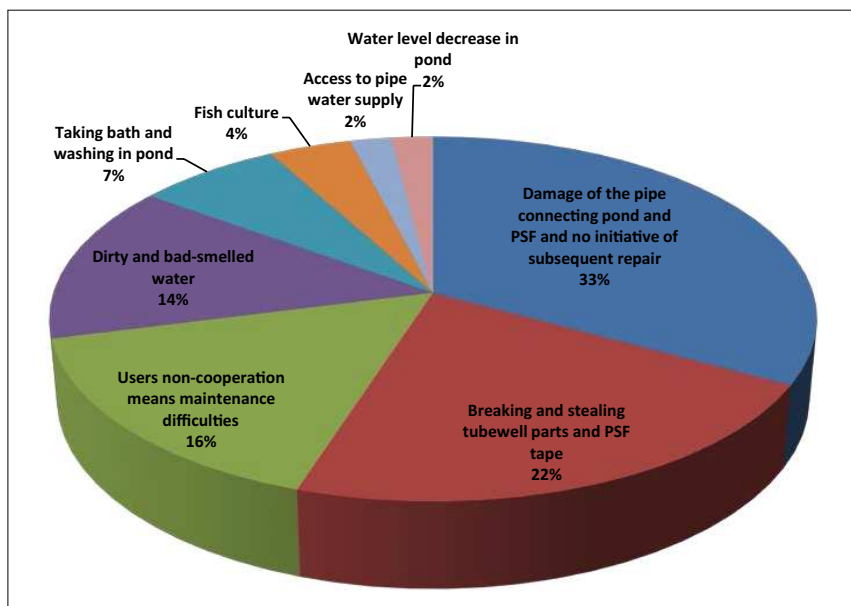

FIGURE 7 | Causes of the failure of PSF-respondents' views.

as own tubewells of the users themselves. About $73 \%$ of the tubewell users are collecting water from the tubewells which are tested and marked by green color, among which $10 \%$ are newly installed wells. The study also found that $24 \%$ households are using untested tubewells, and 3\% people are collecting water from the wells marked by red color.

\section{Reasons for using Unsafe and/or Untested Tubewells} Since tubewells have been the most preferable water option by the communities, the users are familiar and convenient with the operation and maintenance procedure. When a person wants to change his/her water option, tubewell installation is always considered first. Although most of the communities in the survey 
TABLE 8 | Source preference scenario of the surveyed households.

\begin{tabular}{|c|c|c|c|c|c|c|c|c|c|c|c|c|c|c|c|c|}
\hline \multirow[t]{3}{*}{ Purpose of Tubewell Water Use } & \multicolumn{4}{|c|}{ Tubewell use } & \multicolumn{4}{|c|}{ PSF use } & \multicolumn{4}{|c|}{ RWH use } & \multicolumn{4}{|c|}{ River, pond, etc } \\
\hline & \multicolumn{2}{|c|}{ Before } & \multicolumn{2}{|c|}{ Present } & \multicolumn{2}{|c|}{ Before } & \multicolumn{2}{|c|}{ Present } & \multicolumn{2}{|c|}{ Before } & \multicolumn{2}{|c|}{ Present } & \multicolumn{2}{|c|}{ Before } & \multicolumn{2}{|c|}{ Present } \\
\hline & HH \# & HH \% & HH \# & HH \% & HH \# & HH \% & HH \# & HH \% & HH \# & HH \% & HH \# & HH \% & HH \# & HH \% & HH \# & HH \% \\
\hline (A) Drinking only & 92 & $32 \%$ & 171 & $60 \%$ & 32 & $11 \%$ & 7 & $2 \%$ & 27 & $10 \%$ & 3 & $1 \%$ & 7 & $2 \%$ & - & - \\
\hline (B) Cooking only & 2 & $1 \%$ & 7 & $2 \%$ & - & - & - & - & - & - & 1 & $0.4 \%$ & 156 & $55 \%$ & 173 & $61 \%$ \\
\hline (C) Both-drinking and cooking & 73 & $26 \%$ & 83 & $29 \%$ & 42 & $15 \%$ & 13 & $5 \%$ & 7 & $2 \%$ & 5 & - & 4 & $1 \%$ & 2 & $1 \%$ \\
\hline Total $(A+C)$ & 165 & $58 \%$ & 254 & $89 \%$ & 74 & $26 \%$ & 20 & $7 \%$ & 34 & $12 \%$ & 8 & $3 \%$ & 11 & $4 \%$ & 2 & $1 \%$ \\
\hline
\end{tabular}

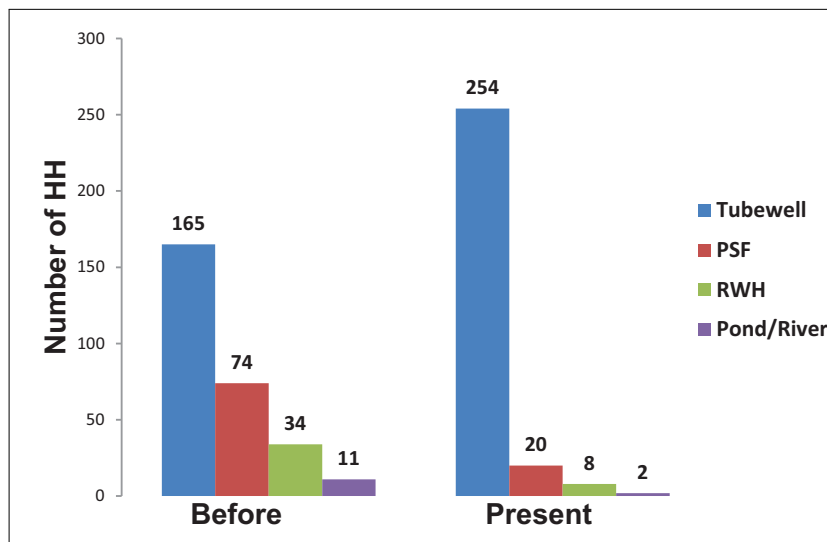

FIGURE 8 | Change in drinking water preference.
Among waters collected from 3 PSF, 2 exceeded the safe levels of pathogenic bacteria. Water of only one RWH was tested since no stored water was found in any other functional RWH during the options survey of the respective household. The results are given in Table 9 below.

\section{Arsenic Test Results of the Functional Tubewells}

Water quality test done for As conducted with the digital arsenator shows all the arsenic-safe tubewells provided, remained safe in terms of As concentration in water produced. Among 55 tubewells functional, As concentration in $89 \%(n=49)$ of the wells was found below/within the WHO guideline value of $10 \mu \mathrm{g} / \mathrm{L}$ and the remaining $11 \%(n=6)$ had the concentration within the Bangladesh drinking water standard of $50 \mu \mathrm{g} / \mathrm{L}$. Within the time frame of 3-4 years, this result has significance in the context of sustainability.

\section{Operation and Maintenance of the Options}

Proper operation and maintenance of the water supply options is an essential requisite for ensuring long-term supply of safe water, which includes timely cleaning of the installation and change of the filtering materials, when required. A good level of knowledge and skill of the users on how to maintain the option and monitor the quality of the water is necessary in this context.

Most of the users were found to be aware about the need to clean the options but a very few people undertake the cleaning work. Maintenance is usually the sole responsibility of the owner/caretaker's house, although the water of the respective option is accessed by other households also. In a situation of no action from the caretaker, the degraded condition compels other users to switch to some other options elsewhere. In some cases, the users switched to open surface water bodies (pond) for their daily household activities.

All of 8 (eight) households using RWH for their water use at present were found to be aware about the need of the cleaning of the options, and their options are being cleaned once in every 6 months.

Among all 20 households presently using PSF, 17 were found to be aware about the cleaning-10 users reported that their PSF is cleaned once in a year and for other 7 households it was twice a year. Regarding the change of filters among PSF users, people from $16 \mathrm{HHs}$ know that the filtering material needs to be changed for ensuring safe water supply. The response on changing the filter was once in every 3 months $(8 \mathrm{HH})$, in 6 months $(5 \mathrm{HH})$ and in every 2 months $(2 \mathrm{HH})$. 
A
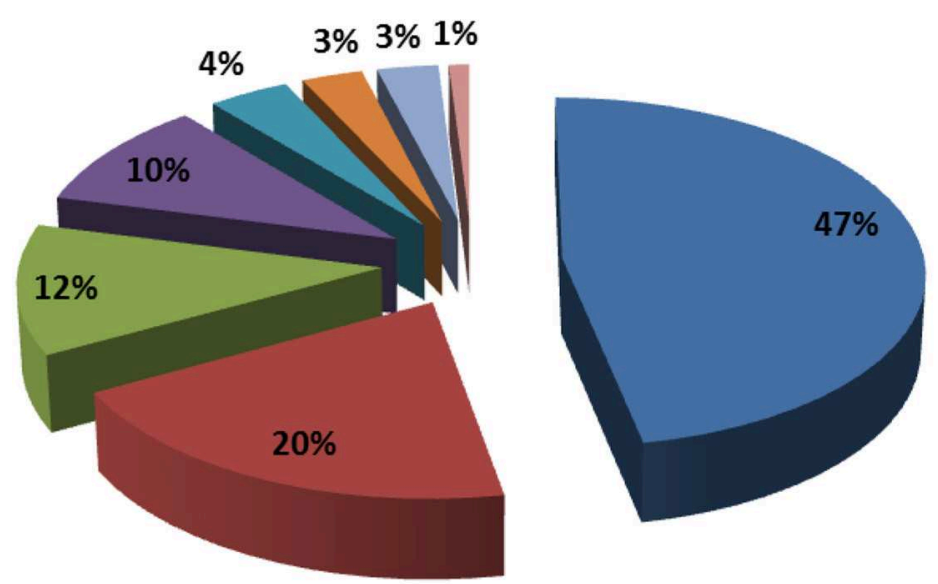

B

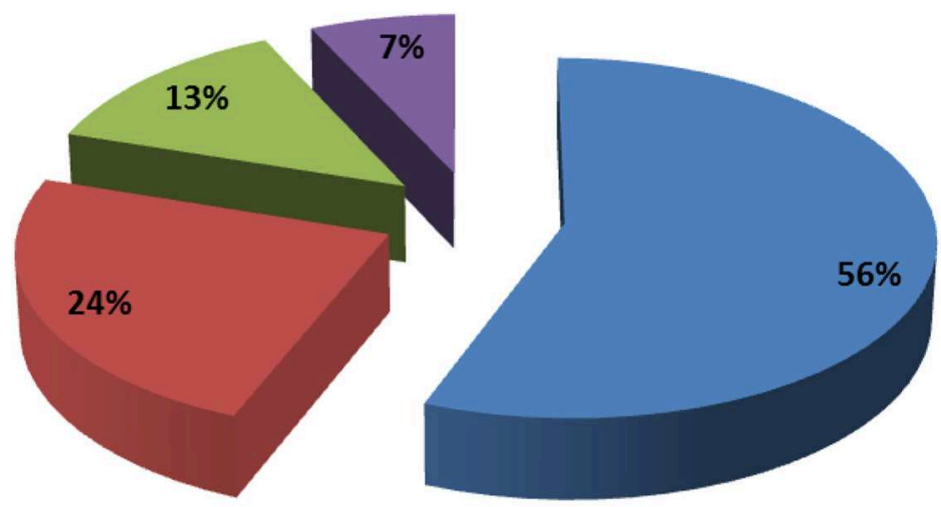

Broken filter, broken and disconnected with pond

Pond in dirty condition caused from fish culture and bad smell in water

Option is not user friendly

Frequent stealing of tap head and filter

Can not use in dry season

Non-functional because of re-digging of pond

Non-cooperation of users in cleaning and repairing

Lack of willingness to collect water by pressing pump

Pipe cracked and/or broken

Rotten leaves from roof-top and insects make water unusable

Pipes taken off from roof-top for repairing the house

No year round rainfall, needed for continuous supply of water

FIGURE 9 | Reasons for switching from (A) PSF and (B) RWH to Tubewell.

\section{Other Factors Relevant to Water use Practice/Preference}

In a country like Bangladesh, livelihood of people and the overall socio-economic condition needs to be accounted with proper consideration. Relevant factors include social and religious acceptance, educational status of the community, cost and easy maintenance compared to the existing technology, presence of other safe water options nearby, selection of suitable site considering the demand and easy access of the targeted users, and their commitment and behavior toward the intervention, etc.

\section{Social and Religious Factor}

RWH was found quite acceptable among the people of Matlab in the context of religious view. Rain being the source of the water, this is considered as the mercy of the creator. The users believe in the purity of this water and to many people this is the purest form of water. Despite the positive response for the RWH from religious attitude and people's liking of the option, it was not found feasible because of the non-availability of water round the year. When the users practice was assessed, almost all the users preferred tubewell water since they can tap water as much as and whenever they need for their drinking and other household purposes.

For PSF, lack and unwillingness of cooperation among the users in the community is a major constraint in its functionality. Since it is a community option, community/users participation for repair, cleaning and maintenance is essential. During the installation of the option, although users' committee had been 
TABLE 9 | TC and FC of water collected from functional PSF and RWH.

\begin{tabular}{|c|c|c|c|c|c|c|c|}
\hline Source & Sample Type & Upazila & Union/Paurashava & Village & Owner/Caretaker & TC & FC \\
\hline PSF-1 & Filtered & $\begin{array}{l}\text { Matlab } \\
\text { South }\end{array}$ & $\begin{array}{l}\text { Matlab } \\
\text { Paurashava }\end{array}$ & Mobarakdi & $\begin{array}{l}\text { Mobarakdi } \\
\text { Orphanage }\end{array}$ & 200 & 0 \\
\hline PSF-2 & Filtered & $\begin{array}{l}\text { Matlab } \\
\text { South }\end{array}$ & $\begin{array}{l}\text { Matlab } \\
\text { Paurashava }\end{array}$ & Mobarakdi & Jalil Mollah & 0 & 0 \\
\hline PSF-3 & Filtered & $\begin{array}{l}\text { Matlab } \\
\text { South }\end{array}$ & Upadi & Uttar Upadi & $\begin{array}{l}\text { Mannan } \\
\text { Prodhania }\end{array}$ & 16 & 8 \\
\hline $\mathrm{RWH}$ & Filtered & $\begin{array}{l}\text { Matlab } \\
\text { South }\end{array}$ & $\begin{array}{l}\text { Matlab } \\
\text { Paurashava }\end{array}$ & Doshpara & $\begin{array}{l}\text { Nasiruddin } \\
\text { Prodhania }\end{array}$ & 0 & 0 \\
\hline
\end{tabular}

formed under the guidance and supervision of the implementing agency and as per policy this committee is responsible for total maintenance and tariff collection. But in long run, the users' committees have been found inactive. During our study most of the times cleaning and changing of the filter material and maintaining water level in the storage tank was found to be the sole responsibility for the pond owner, but monetary contributions from other users were found absent. As a consequence, the respective caretaker lose his/her interest to maintain the PSF and at some time start commercial fish culture, which in turns, make the water option unusable for consumption.

\section{Gender}

In terms of water collection for drinking and other household activities, gender has always been an important issue in rural Bangladesh (Hoque et al., 2004). In fact water collection for drinking and domestic purposes is always being done by the household women (Hoque et al., 2004; Singh et al., 2008). Household women in Matlab regardless of religion and age do not prefer to go far to fetch water, which is to some extent social conservativeness and excessive physical labor. The attitude of the woman regarding collection of water and that of the household members prefer to collect drinking water from a nearby source, made tubewell a preferred option rather than PSF, since the tubewell, in most cases, is usually in close proximity to the house.

During the study it was also observed that awareness for motivating the household women is still required to uphold the importance of using safe water required for health and hygiene of the family. In village Nagda under Khadergaon union of Matlab south upazila, a man suffering from arsenicosis was found collecting arsenic-safe water from a distant arsenic-safe tubewell only for him, while the wife and a 2 -year old child were found drinking water from a nearby unsafe tubewell. The respective woman believes that As-safe water is needed for the identified patient only, which indicates that there is still a knowledge gap among the women and hence more motivational programs are still required in the area.

\section{Design of the Technology}

RWH is normally designed in such a way which usually serves the requirement of a family having 4-5 members. In many cases, in the study area, it was found that the families live in a joint-family culture, which has been a traditional way of living in this country for many years. When such families with 8-10 members use a RWH, storage for considerable time period becomes a concern. At the same time, distribution patterns (location) of households in a densely populated area neither favor installation of a bigger option nor does the house owner permit it. Despite having a suitable RWH with proper maintenance and willingness to use, those still using this option have difficulty in getting year round supply of water.

Since PSF is a community based option it is essential that the water collection site should be constructed in a public place. As a result security of the equipment is a problem and frequent stealing of the pumping tubewell parts and the tape head occurred. As a result the maintenance costs became high and the users lost their interest in operating and maintaining the option.

\section{Choice of the Site}

Inappropriate site selection for PSF was found to be as a significant problem. Although water level in the pond generally goes down during the dry season, but during the option assessment survey, it was apparent that some ponds are more susceptible to water level decline compared to others and that could be probably because of the hydrogeological condition of the pond site and adjacent areas. Water level drops down to such a level that makes the transfer of water from pond to the tank difficult. Moreover, the excessive lowering of water level enhances the degradation of water quality, in particular with increasing coliform density. Therefore, it is crucial to consider the hydrogeological condition of the location to select any pond for the installation of a PSF in order to ensure minimum base flow loss (subsurface percolation) from the pond.

\section{Education and Economy}

There was no significant difference in water use pattern for users having different levels of education, although the rate of abandonment of PSF and RWH and thereby the enhancement of dependence on tubewell was found more among the households having education higher than the secondary level. Among the tubewell users, tubewell water use for both drinking and cooking compared to drinking only was observed relatively more among the people with better education (Figure 10). Similar observation was noticed for better maintenance and cleaning also. Despite the variation of education among all users, tubewell was found to be the most popular option.

Household economic status also has an impact on water use pattern-more solvent $\mathrm{HH}$ is more conscious for their day to 


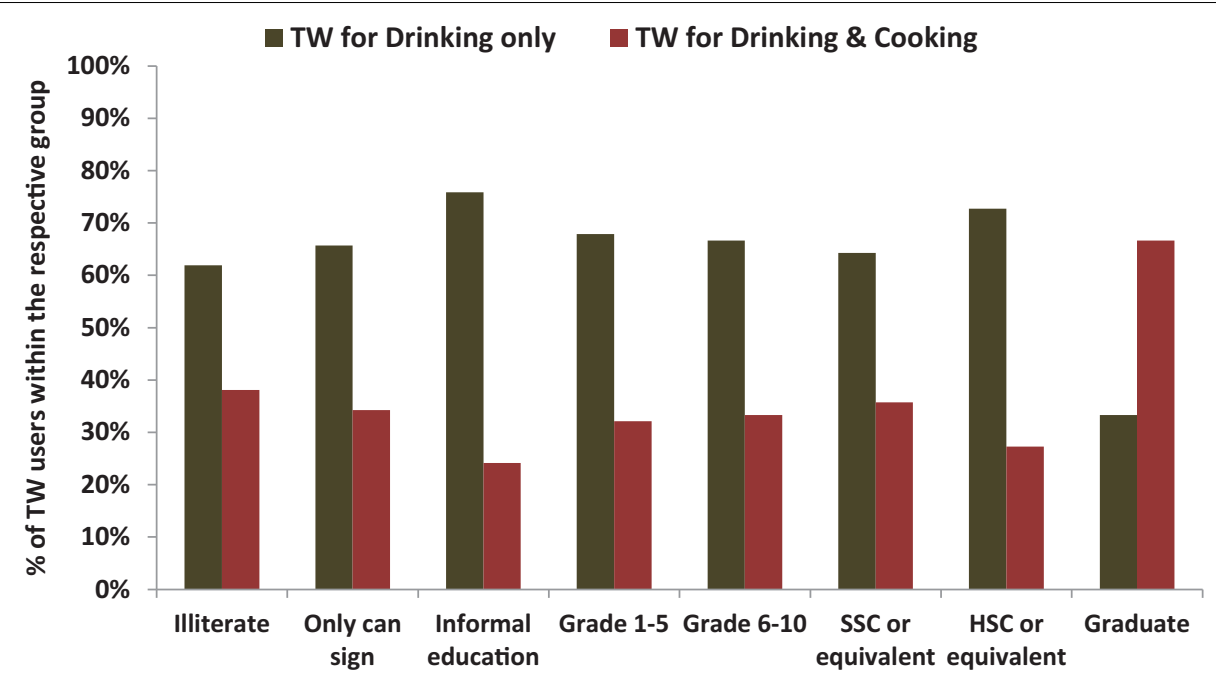

FIGURE 10 | Influence of education on user's preference for use of Tubewell water.

day water use pattern. Use of tubewell water for both drinking and cooking compared to drinking only was observed more among the relatively solvent $\mathrm{HH}$. Figure 11 illustrates the relation between the financial status of households (determined from the availability of food) and the preference of tubewell water use.

In terms of operation and maintenance, PSF and RWH were found to be better operational in the family clusters having sound financial condition. They were found cooperative to each other for bearing the cost incurred from repairing of the water options. Health condition of the family members gets less concern among the poor families who needs to work hard for managing food only. Hence in introducing a new technology in a poor community it is crucial that the technology should be cost-effective compared to the existing options, otherwise a long term software activity is needed to motivate the people to use the newer one.

Household economy played a major role in functionality of filters among the villagers of the study area. In addition to complicacy, costly maintenance of the systems turned the users gradually to abandon the option and eventually they went back to the comparatively easy maintaining and technologically friendly tubewells for their day to day water use.

\section{Discussions and Conclusion}

All kinds of arsenic removal filters and those provided for filtering surface water were found not in use, which means, $100 \%$ of the filters became abandoned. Among the other safe drinking water options distributed, $13 \%$ of PSF, $40 \% \mathrm{RWH}$, and $93 \%$ of tubewell were found functioning. In all cases, installed arsenicsafe tubewells were found to remain as arsenic-safe. In terms of households, tubewell users were $58 \%$ before and as a consequence of providing safe water options, it has been increased to $89 \%$ at present. On the contrary, $26 \%$ of PSF use has been reduced to $7 \%$ and similarly use of RWH by $12 \%$ households was reduced to $3 \%$ only.

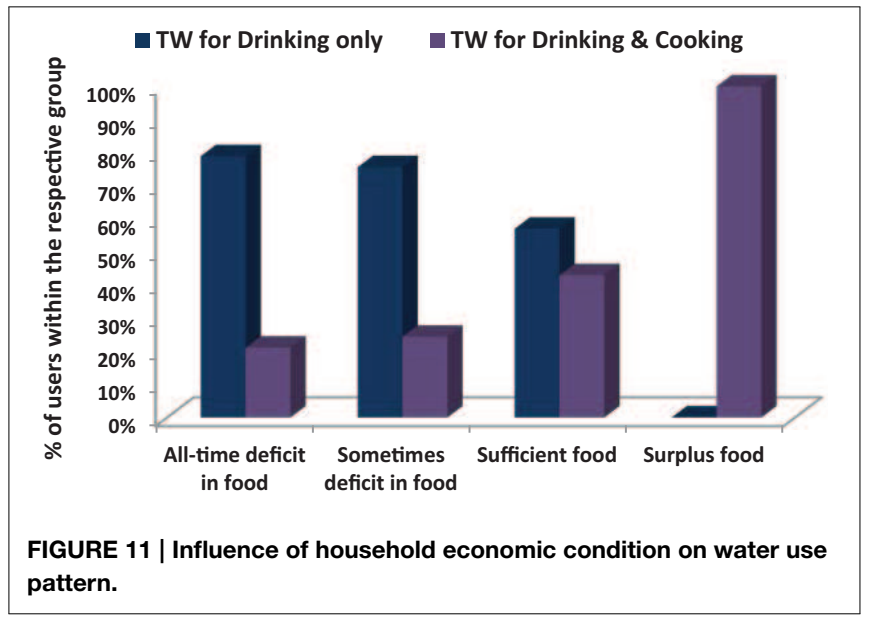

Filters were abandoned by the users for their high cost and complicated maintenance, which is also quite expensive. Sludge management was also a concern. The use of PSF and RWH is not as user friendly as tubewell and ensuring year round water quality is also a big challenge. For these two options, various social and technological constraints also caused their non-functionality. As the reason for abandoning the community based option PSF, technical problem was mentioned most, followed by other reasons, such as, costly maintenance, broken or stealing of tape and pumping tubewell parts, users non-cooperation in maintenance, water quality and decreased water level in dry season. Since RWH is the household based water supply option, operation and maintenance of this option solely depends on the household. The reasons observed against inactiveness of RWH in chronological order are damaged pipe for collecting water from roof; damaged chakti, net, filter, tape, tank cover, etc.; maintenance difficulties; bad water quality due to rotten leaves; insects on house roof; no year round rainfall for continuous supply of water; disconnection of pipe due to house shifting and new house construction etc. 
Arsenic-safe tubewell was found widely accepted option mainly because of easy operation, good water quality and negligible maintenance. This study validated tubewell as the most feasible drinking water supply option and this evaluation holds significance for planning water supply project, improving mitigation policy as well as developing awareness among people.

When we prescribe mitigation options for any of the relevant stakeholders including end users to policy people, besides providing arsenic-safe water to the affected people, it is also important to consider any adverse effects of the prescribed interventions and how it works in the overall framework of disease burden reduction. Lokuge et al. (2004) examined the disease burden effect in different scenario for different interventions and indicated that the increase in water-related infectious disease develop simultaneously from certain options could significantly reduce the ultimate benefits of those interventions. Burden of disease associated with different mitigation options were calculated by Howard et al. (2006) based on water quality assessment and indicated PSF could cause higher burden of disease from heavy microbial contamination during both dry and monsoon periods and good quality water of RWH during monsoon deteriorates in the dry season. Quality of collected rainwater in RWH is largely affected from dirt and bird droppings during dry season (Islam et al., 2014). These findings support the result of the current study which shows PSF and RWH are less preferred option compared to tubewell.

Johnston et al. (2014) looked at arsenic mitigation in Bangladesh based on the investigations from three important aspects, such as, institutional, psychological, and technical and found tubewell (deep tubewell in their findings) as the most preferred option that could bring a significant change in the scenario of arsenic mitigation.

In order to minimize health risk from the arsenic exposure, finding an acceptable water option is an important issue. It could be either a new arsenic-safe water source or arseniccontaminated water produced from the existing source to be treated. In either case, the ultimate supplied water must be arsenic-safe as well as free from other chemical and bacteriological contamination. The safe disposal of arsenic sludge is a very important environmental concern for which the standards, methods and management are yet to be established. Other than water quality and environmental issues, ease of operation and cost of maintenance and the acceptance to the users (society) are crucial in the context of sustainability of safe water options. Awareness of the safe water in the context of health and attitude toward collecting safe water are also crucial in reducing the

\section{References}

Ahmed, K. M., Bhattacharya, P., Hasan, M. A., Akhter, S. H., Alam, S. M. M., Bhuyian, M. A. H., et al. (2004). Arsenic contamination in groundwater of alluvial aquifers in Bangladesh: an overview. Appl. Geochem. 19, 181-200. doi: 10.1016/j.apgeochem.2003.09.006

Ahmed, M. F., Ahuja, S., Alauddin, M., Hug, S. J., Lloyd, J. R., Pfaff, A., et al. (2006). Ensuring safe drinking water in Bangladesh. Science 314, 1687-1688. doi: $10.1126 /$ science. 1133146 exposure to arsenic contamination. This study revealed that negligence and unavailability of a safe tubewell in a close proximity were the important reasons for using unsafe tubewell as the drinking water source. Inauen et al. (2013) conducted a survey in 2009 to look at the acceptance and use of different safe drinking water options and found $62 \%$ of 872 respondents were using safe water option although all had access to at least one alternative. In their findings, people not using safe water sources were characterized by greater vulnerability, not articulate to social values and norms, lack of confidence/belief in survival with better planning, and therefore the willingness for collecting safe water was also weak.

Although in terms of user's acceptance and functionality, tubewells were found very well performing, but in the context of water safety plan it is very important to consider all water quality parameters related to health and hence need periodical monitoring. User's participation and knowledge on the testing system and awareness are important for the sustainability of safe water options. Field based research and review of available information on existing water options, their acceptability to the users, peoples demand and assessment of the socio-economic condition of the targeted population should get proper importance for bringing any improvement of the existing technology and/or introducing any technology in a locality. The wide acceptability of tubewells will eventually promote tubewell installation further in the country and therefore importance lies with a comprehensive research with proper scientific basis toward easy identification of safe aquifers which could be explored and exploited for the sustainable use of groundwater resources and management. For bringing a visible change in safe water access, specially targeting the poor and disadvantage community, it is important to promote an option which is socially accepted, technically simple and feasible, which the local community can adopt by themselves for the installation of their own safe drinking water option. At the time of technology promotion strong motivation and continued research on evaluation of social acceptance to identify the cross-cutting factors should also be taken into account.

\section{Acknowledgments}

The authors thankfully acknowledge the Swedish International Development Cooperation Agency (Sida) for the financial support through the Sida-SASMIT project (Sida Contribution 75000854). We greatly acknowledge the participations of the respondents for their cordial support during the interview process.
AsMat Final Report. (2007). Arsenic in Tube Well Water and Health Consequences, Sida Final Report, Dhaka.

BBS. (2011). Bangladesh Population and Housing Census 2011, Bangladesh Bureau of Statistics (BBS), Statistics and Informatics Division (SID), Ministry of Planning, Government of Bangladesh (Dhaka).

BBS/UNICEF (Bangladesh Bureau of Statistics/United Nations Children's Fund) (2011). Bangladesh National Drinking Water Quality Survey of 2009. UNICEF, Dhaka, Bangladesh, 192. 
BGS and DPHE. (2001). "Arsenic contamination of groundwater in Bangladesh," in Volume 1: Summary. British Geological Survey Report WC/00/19, eds D. G. Kinniburgh and P. L. Smedley (Keyworth: British Geological Survey).

Bhattacharya, P., Jacks, G., Ahmed, K. M., Khan, A. A., and Routh, J. (2002). Arsenic in groundwater of the bengal delta plain aquifers in bangladesh. Bull. Environ. Contam. Toxicol. 69, 538-545. doi: 10.1007/s00128-002-0095-5

DPHE/JICA. (2010). Situation Analysis of Arsenic Mitigation 2009. Dhaka: Department of Public Health Engineering, Government of Bangladesh, and Japan, International Cooperation Agency.

Flanagan, S. V., Johnston, R. B., and Zheng, Y. (2012). Arsenic in tube well water in Bangladesh: health and economic impacts and implications for arsenic mitigation. Bull. World Health Organ. 90, 839-846. doi: 10.2471/BLT.11.101253

Hoque, B. A., Hoque, M. M., Ahmed, T., Islam, S., Azad, A. K., Ali, N., et al. (2004). Demand-based water options for arsenic mitigation: an experience from rural Bangladesh. Public Health 118, 70-77. doi: 10.1016/S0033-3506(03)00135-5

Hossain, M., Bhattacharya, P., Frape, S. K., Jacks, G., Islam, M. M., Rahman, M. M., et al. (2014). Sediment color tool for targeting arsenic-safe aquifers for the installation of shallow drinking water tubewells. Sci. Total Environ. 493, 615-625. doi: 10.1016/j.scitotenv.2014.05.064

Howard, G., Ahmed, M. F., Shamsuddin, A. J., Mahmud, S. G., and Deere, D. (2006). Risk assessment of arsenic mitigation options in Bangladesh. J. Health Popul. Nutr. 24, 346-355.

Inauen, J., Hossain, M. M., Johnston, R. B., and Mosler, H.-J. (2013). Acceptance and use of eight arsenic-safe drinking water options in Bangladesh. PLoS ONE 8:e53640. doi: 10.1371/journal.pone.0053640

Islam, M. M., Chou, F., Maity, J. P., and Kabir, M. R. (2014). Rainwater harvesting: an alternative source of safe drinking water in Bangladesh. Austin J. Hydrol. $1,1-8$.

Jakariya, M., Rahman, M., Chowdhury, A. M. R., Rahman, M., Yunus, M., Bhuiya, M. A., et al. (2005). "Sustainable safe water options in Bangladesh: experiences fromthe Arsenic Project at Matlab (AsMat)," in Natural Arsenic in Groundwater: Occurrence, Remediation and Management, eds J. Bundschuh, P. Bhattacharya, and D. Chandrasekharam (London: Balkema), 319-330.

Jakariya, M., Vahter, M., Rahman, M., Wahed, M. A., Hore, S. K., Bhattacharya, P., et al. (2007). Screening of arsenic in tubewell water with field test kits: evaluation of the method from public health perspective. Sci. Total Environ. 379, 167-175. doi: 10.1016/j.scitotenv.2006.11.053

Johnston, R., Hug, S. J., Inauen, I., Khan, N. I., Mosler, H. J., and Yang, H. (2014). Enhancing arsenic mitigation in Bangladesh: findings from institutional, psychological and technical investigations. Sci. Total Environ. 488-489, 477-483. doi: 10.1016/j.scitotenv.2013.11.143

Johnston, R., and Sarker, M. (2007).Arsenic mitigation in Bangladesh: national screening data and case studies in three upazilas. J. Environ. Sci. Health A 42, 1889-1896. doi: 10.1080/10934520701567155

Khan, A. H., Rasul, S. B., Munir, A. K. M., Habibuddowla, M., Alauddin, M., Newaz, S. S., et al. (2000). Appraisal of a simple arsenic removal method for groundwater of Bangladesh. J. Environ. Sci. Health A 35, 1021-1041. doi: $10.1080 / 10934520009377018$
Khan, N. I., Brouwer, R., and Yang, H. (2014). Household willingness to pay for arsenic-free drinking water in Bangladesh. J Environ. Manag. 143, 151-161. doi: 10.1016/j.jenvman.2014.04.018

Khan, N. I., Bruce, D., Naidu, R., and Owens, G. (2009). Implementation of food frequency questionnaire for the assessment of total dietary arsenic intake in Bangladesh: part B, preliminary findings. Environ. Geochem. Health 31, 221-238. doi: 10.1007/s10653-008-9232-3

Lokuge, K. M., Smith, W., Caldwell, B., Dear, K., and Milton, A. H. (2004). The effect of arsenicmitigation interventions on disease burden in Bangladesh. Environ. Health Perspect. 112, 1172-1177. doi: 10.1289/ ehp6866

Mukherjee, A. B., and Bhattacharya, P. (2001). Arsenic in groundwater in the bengal delta plain: slow poisoning in Bangladesh. Environ. Rev. 9, 189-220. doi: 10.1139/er-9-3-189

Shamsudduha, M., and Uddin, A. (2007). Quaternary shoreline shifting and hydrogeologic influence on the distribution of groundwater arsenic in aquifers of the Bengal Basin. J. Asian Earth Sci. 31, 177-194. doi: 10.1016/j.jseaes.2007. 07.001

Singh, N., Jacks, G., and Bhattacharya, P. (2008). "Ensuring arsenic-safe water supply in local communities: emergent concerns in West Bengal, India," in Groundwater for Sustainable Development: Problems, Perspectives and Challenges, eds P. Bhattacharya, A. L. Ramanathan, A. B. Mukherjee, J. Bundschuh, D. Chandrasekharam, and A. K. Keshari (Leiden: Taylor and Francis/A.A. Balkema), 357-364.

van Geen, A., Zheng, Y., Goodbred, S., Horneman, A., Aziz, Z., Cheng, Z., et al. (2008). Flushing history as a hydrogeological control on the regional distribution of arsenic in shallow groundwater of the Bengal Basin. Environ. Sci. Technol. 42, 2283-2288. doi: 10.1021/es702316k

van Geen, A., Zheng, Y., Versteeg, R., Stute, M., Horneman, A., Dhar, R. K., et al. (2003). Spatial variability of arsenic in 6000 tubewells in a 25 $\mathrm{km} 2$ area of Bangladesh. Water Resour. Res. 39, 1140. doi: 10.1029/2002 WR001617

von Brömssen, M., Jakariya, M., Bhattacharya, P., Ahmed, K. M., Hasan, M. A., Sracek, O., et al. (2007). Targeting low-arsenic aquifers in groundwater of Matlab Upazila, Southeastern Bangladesh. Sci. Total Environ. 379, 121-132. doi: 10.1016/j.scitotenv.2006.06.028

Conflict of Interest Statement: The authors declare that the research was conducted in the absence of any commercial or financial relationships that could be construed as a potential conflict of interest.

Copyright (c) 2015 Hossain, Rahman, Bhattacharya, Jacks, Saha and Rahman. This is an open-access article distributed under the terms of the Creative Commons Attribution License (CC BY). The use, distribution or reproduction in other forums is permitted, provided the original author(s) or licensor are credited and that the original publication in this journal is cited, in accordance with accepted academic practice. No use, distribution or reproduction is permitted which does not comply with these terms. 